\title{
FAMILIES ARE MORE POPULAR THAN FEMINISM: EXPLORING THE GREATER JUDICIAL SUCCESS OF FAMILY AND MEDICAL LEAVE LAWS
}

\author{
KATE WEBBER*
}

"Rather than focusing on prohibiting discrimination on the basis of gender, one might ask what work should look like."

\section{INTRODUCTION}

Two federal employment laws advance women's position in the workplace, but one has been much more successful than the other when employee plaintiffs seek to enforce their rights in court. First, Title VII of the Civil Rights Act of 1964 ("Title VII") prohibits sex discrimination in the workforce. Plaintiffs seeking to enforce this statute experience one of the lowest success rates of any civil cause of action. ${ }^{2}$ On the other hand, the Family Medical Leave Act of 1993 ("FMLA") provides employees the right to take leave for the birth of a child, medical or family care, and prohibits discrimination against those who use their leave rights. Employees who bring cases under the FMLA have nearly double the chance of winning in court compared with anti-discrimination statutes such as Title VII. ${ }^{3}$ The FMLA is more successful despite the fact that, like Title VII's sex discrimination prohibitions, the FMLA benefits women in particular, providing a key support to their workplace advancement. This Article examines the potential causes of the different litigation success rates of Title VII and the FMLA. In doing so, the Article sheds light on

* Associate Professor of Law, Nova Southeastern University Shepard Broad College of Law.

1 Catherine R. Albiston, Institutional Inequality and the Mobilization of the Family and Medical LEAVE ACT, 106 (2010).

2 Kevin M. Clermont \& Stewart J. Schwab, Employment Discrimination Plaintiffs in Federal Court: From Bad to Worse?, 3 Harv. L. \& PoL'y Rev. 103, 127 (2009) (Between 1979 and 2006, the plaintiff win rate in federal court for "jobs cases" (15\%) was dramatically lower than for "nonjobs cases" $(51 \%)$ ) [hereinafter Clermont \& Schwab, From Bad to Worse].

3 Katie R. Eyer, That's Not Discrimination: American Beliefs and the Limits of Anti-Discrimination Law, 96 Minn. L. REv. 1275, 1352 (2012) (FMLA claimants win pretrial adjudications at roughly four times the rate of discrimination litigants, and prevail at trial in roughly sixty percent of cases) (citing Kevin M. Clermont \& Stewart J. Schwab, How Employment Discrimination Plaintiffs Fare in Federal Court, 1 J. EMPIRICAL LEGAL STud. 429, 445 (2004) [hereinafter Clermont \& Schwab, How Plaintiffs Fare]). 
judicial decision-making in employment law and suggests avenues for advocates seeking to change women's work life for the better.

Understanding what makes the FMLA successful is of current import because there are many proposed and recently-enacted laws, which, like the FMLA, provide leave benefits to workers. For example, a number of states and municipalities have passed laws to expand employees' ability to take leave from work to care for family or medical issues. ${ }^{4}$ The federal Department of Labor has launched an initiative to support these state and local efforts. ${ }^{5}$ News coverage further reflects a cultural concern with the issue and an increasing awareness of how employees' limited rights to take leave from work prevent them from addressing their personal or family needs. ${ }^{6}$ Given the momentum and interest in leavebased legal reform, it is appropriate to explore how leave laws will be received in the courts when the inevitable need to enforce them arises.

This Article uses three theoretical frameworks - political, psychological, and institutional - to explore how and why cases under the FMLA, and by extension other leave laws, can escape the dismal litigation fates of the anti-discrimination law. Political science theories suggest that the FMLA is more successful because the statute is less controversial and inspires a weaker ideological response in judges than anti-discrimination laws. The theory of cultural cognition suggests that the FMLA is more successful because it does not trigger the strong unconscious resistance associated with discrimination claims. Finally, theories of institutional inequality indicate that the FMLA is more successful because it can undermine the traditional norms of the ideal worker in ways that the anti-discrimination laws cannot. Overall, all three theories point to a consistent explanation for why FMLA claims have better outcomes. Namely, leave laws such as the FMLA have many of the characteristics of a neutral benefit statute, in contrast to anti-discrimination laws' focus on protected classes such as race or gender. Ultimately, understanding what differentiates the outcomes between these related statutes will suggest the best avenues for advocates of gender equality in the workplace.

Part I of the Article introduces the FMLA and other laws affecting an employee's ability

4 See, e.g., CAL. Unemp. Ins. Code Ann. § 2601 (West 2015) (providing for paid family leave).

5 We're Ready to Lead on Leave, U.S. DeP'т LAB. Blog (Jan. 17, 2015), http://blog.dol.gov/2015/01/15/ were-ready-to-lead-on-leave/ [https://perma.cc/SN33-VSHA].

6 See, e.g., Claire Cain Miller, New Momentum in Paid Leave, in Business and in Politics, N.Y. Times, June 22, 2015, at B1; Paula Span, Caregivers Must Sometimes Sacrifice Their Careers, N.Y. Times, Dec. 5, 2015, at D5. 
to take leave for family care responsibilities. Part II.A looks at the political science models of judicial decision-making and asks whether leave laws such as the FMLA succeed because they are less controversial, or less ideological, than protected class-based statutes. Part II.B looks at the theories of cultural cognition to determine whether they can explain leave laws' relative success. Finally, Part II.C explores the framework of institutional inequality, or the way internalized notions of the ideal worker prevent laws such as Title VII from truly transforming the position of women within the workplace. The Article concludes with the implications for advocates seeking to reform the workplace.

\section{Background}

To understand why and how leave laws such as the FMLA may be a better tool for workplace equality, it is necessary to first understand what leave laws regulate, where these laws fit within the context of employment law, and how courts respond to leave laws in particular. All of these statutes attempt to mitigate the conflict between work and family needs by requiring employers to offer benefits to their workers.

\section{A. The Family Medical Leave Act and Expanded Leave Benefits}

A variety of leave laws provide employees with the ability to take time off from work to care for family or themselves. At the federal level, the FMLA is the most important statute, granting leave rights to millions of workers nationwide. ${ }^{7}$ The FMLA requires employers with fifty or more employees to provide covered workers up to twelve weeks of unpaid, job-protected leave: for the birth or adoption of a child, for their own serious medical condition, or to care for a close relative with a serious medical condition. ${ }^{8}$ Only employees who have worked for at least a year, and 1,250 hours within the past year, can qualify. ${ }^{9}$ The employee who takes leave must be restored to the same or equivalent position and the employer cannot retaliate against the employee for taking the leave. ${ }^{10}$

729 U.S.C. $\S 2601$.

829 U.S.C. $\S \S 2611(4), 2612$ (a)(1). In 2008, the FMLA was amended to provide two types of military family leave: (i) up to twelve workweeks of job-protected leave for any "qualifying exigency" arising out of the active duty or call to active duty status of a spouse, son, daughter, or parent; and (ii) up to twenty-six workweeks of job-protected leave in a "single 12-month period" to care for a covered service member with a serious injury or illness. National Defense Authorization Act for Fiscal Year 2008, 29 USC § 2612(3).

929 U.S.C. $\S 2611(2)(A)$.

1029 U.S.C $\S \S 2614(a)(1), 2615(a)(2)$. 
State laws also provide crucial leave rights to workers, and some provide expanded benefits beyond what the FMLA offers. For example, in response to the need for compensation and time for family care, four states, California, New Jersey, Rhode Island, and New York, have enacted laws providing for at least a few weeks of paid family leave. ${ }^{11}$ The absence of paid leave is one of the most widely criticized aspects of the FMLA. ${ }^{12}$ Relatedly, several states have enacted laws requiring paid, short-term sick leave. ${ }^{13}$ The

11 Cal. Unemp. Ins. Code Ann. § 2601 (West 2015); N.J. Stat. Ann. § 43:21-25 (West 2015); R.I. Gen. Laws ANN. §§ 28-41-34-28-41-38 (West 2015). California's paid leave statute was effective in 2004 and provides for up to 6 weeks of paid leave in the amount of up to $55 \%$ of wages (the wage replacement is capped). CAL. UnEmp. Ins. CoDE AnN. § 3301 (West 2015). In 2009, New Jersey's paid family leave law became effective; it provides for up to 6 weeks of paid leave in the amount of $2 / 3$ of weekly salary (the wage replacement is capped). N.J. Stat. AnN. § 43: 21-38 (West 2015). In 2013, Rhode Island passed a paid family leave law providing for 4 weeks of paid family leave of approximately $60 \%$ of wages (the wage replacement is capped). 28 R.I. Gen. Laws ANN. § 28-41-34 (West 2015). In April 2016, New York enacted a paid family leave law that when fully implemented will provide 12 weeks of paid leave at $67 \%$ of wages. N.Y. WorKERs' ComP. LAW § 204 (McKinney 2016). President Obama also signed a Presidential Memorandum granting federal employees 6 weeks of paid parental leave. Modernizing Federal Leave Policies for Childbirth, Adoption and Foster Care to Recruit and Retain Talent and Improve Productivity, WhiтeHouse.Gov (Sept. 7, 2015), https:// www.whitehouse.gov/the-press-office/2015/01/15/presidential-memorandum-modernizing-federal-leavepolicies-childbirth-ad [https://perma.cc/DGT8-UK5B].

12 Nicole Buonocore Porter, Finding a Fix for the FMLA: A New Perspective, a New Solution, 31 HoFstrA LAB. \& EMP. L.J. 327, 343-44 (2014) (noting that the most commonly made suggestion for improving the FMLA is to provide for paid leave). Both Democratic presidential candidates have called for paid family leave. See Hillary Clinton, https://www.hillaryclinton.com/issues/paid-leave/ [https://perma.cc/T2WH-6KP3] (last visited June 26, 2016); BERNIE SANDERs, https://berniesanders.com/issues/real-family-values/ [https://perma. cc/363Y-DB25]. Every other industrialized democracy offers paid leave. Ann Bartel, et al., Paid Family Leave, Fathers' Leave-Taking, and Leave-Sharing in Dual-Earner Households 5 (Nat'l Bureau of Econ. Research, Working Paper No. 21747, 2015). The failure to do so in the United States is particularly punitive to lowerincome workers who cannot afford time off without pay. See Porter, supra note 12, at 340.

13 A Better Balance, Overview of Paid Sick Time Laws in the United States, 1-4 (2015), http://www. abetterbalance.org/web/images/stories/Documents/sickdays/factsheet/PSDchart.pdf [https://perma.cc/VT8QJSX3] [hereinafter Overview of PAID Sick TIME]. California's sick leave law, passed in September 2014, provides up to 24 hours of paid sick time. CAL. LAB. CODE $\S 246$ (West 2015). In Massachusetts, the sick leave law passed November 2014, and provides workers with up to 40 hours of paid sick time a year. Mass. Gen. Laws AnN. ch. 149, § 148C(d)(4) (West 2015). Connecticut's sick leave law applies to employers with 50 or more employees and provides for up to 40 hours of paid sick leave per year. Conn. Gen. Stat. Ann. §§ 31-57r-31-57w (West 2015). In Oregon, workers whose employers have at least 10 employees can earn up to 40 paid hours of sick time per year. S.B. 454, 78th Leg. Assemb., Reg. Sess. (Or. 2015). Smaller employers must provide job-protected sick leave of 40 hours a year, but are not required to pay for this time. Id. All of these states allow employees to use the time to care for a close family member as well as their own illness. Overview of Paid Sick Time, supra note 13, at 1-4. 
federal government has also made some efforts to offer paid sick leave. ${ }^{14}$ The nearly forty million workers who have no sick leave benefits must either work while sick or risk the financial harm of losing the day's wage or even losing their job for failing to appear for work. ${ }^{15}$ Paid sick leave is recognized as an important supplement to the FMLA for lowwage workers because it provides for time off for the less serious illnesses that the FMLA does not cover. ${ }^{16}$

In addition to these enacted leave laws, legislators and advocates have offered other bills that address the conflict between work and family needs. There are efforts to enact paid family leave at the state level in New York, Washington, Connecticut, and New

14 On September 7, 2015, President Obama signed an executive order "requiring federal contractors to provide up to seven days of paid sick leave a year." President Barack Obama, Remarks by the President at Greater Boston Labor Council Labor Day Breakfast (Sept. 8, 2015); Fact Sheet: Helping Middle-Class Families Get Ahead by Expanding Paid Sick Leave, WhiтeHouse.Gov (Sept. 7, 2015), https://www.whitehouse.gov/ the-press-office/2015/09/07/fact-sheet-helping-middle-class-families-get-ahead-expanding-paid-sick [https:// perma.cc/9NQ2-HHAD]. See also Peter Baker, Obama Orders Federal Contractors to Provide Workers Paid Sick Leave, N.Y. Times, Sept. 7, 2015, at A20 (noting the contractor sick leave order must first go through a public comment period and will apply only to new federal contracts starting in 2017, but "the White House hopes it will set a standard that will prod lawmakers, private employers, and state and local governments to expand their leave policies."). President Obama also signed a Presidential Memorandum directing federal agencies to advance up to six weeks of paid sick leave for parents with a new child. Presidential Memorandum-Modernizing Federal Leave Policies for Childbirth, Adoption and Foster Care to Recruit and Retain Talent and Improve Productivity, WhiтeHouse.Gov (Jan. 15, 2015), https://www.whitehouse.gov/thepress-office/2015/01/15/presidential-memorandum-modernizing-federal-leave-policies-childbirth-ad [https:// perma.cc/HW5F-7RJR]. A proposed federal law, the Healthy Families Act, would allow millions of workers to earn up to seven days of paid sick leave per year. Healthy Families Act, H.R. 1286, 113th Cong. (2013). Specifically, workers in businesses with at least 15 employees could earn 7 job-protected, paid sick days and use them to recover from their own illnesses, access preventive care, provide care to a sick family member, or attend school meetings related to a child's health condition or disability. Id. Workers at businesses with fewer than 15 employees could earn 7 job-protected but unpaid sick leave days to be used for the same purposes. Id.

15 "Workers without paid sick days - nearly 40 percent of the private-sector workforce - are among the least economically secure, and an illness forces them to take time away from work without pay and puts them at risk of losing their job. Lack of paid sick time means that an illness can potentially cost a family thousands of dollars in income and jeopardize their ability to afford food, rent, health insurance, and many of the other basic goods that are essential to well-being. Just three and a half days of missed work because of illness is equivalent to an entire month's groceries for the average family." Elis Gould ET AL., ECON. Policy InST., The NeEd for PAID Sick DaYs 1 (2011).

16 Porter, supra note 12, at 340; Katharine B. Silbaugh, Is the Work-Family Conflict Pathological or Normal Under the FMLA? The Potential of the FMLA to Cover Ordinary Work-Family Conflicts, 15 WASH. U. J.L. \& POL'y 193, 193-94 (2004). 
Hampshire. ${ }^{17}$ Ongoing legislative efforts seek to provide paid leave on a national basis. ${ }^{18}$ Various municipalities have similarly proposed laws to require employers to provide paid or at least job-protected sick leave benefits. ${ }^{19}$

\section{B. The Context of Leave Laws}

All of the existing, new and proposed leave laws offer benefits for workers, but to be fully effective, courts must enforce these statutes. ${ }^{20}$ Benefits are not meaningful if employers may deny them without penalty. The question of enforcement is particularly relevant here because with other comparable employments statutes, namely the anti-discrimination laws, plaintiffs routinely lose their cases. Thus, the next steps for understanding the impact of leave laws is to place these statutes within a broader legal context, comparing them to the less successful employment statutes.

\section{Context of Leave Laws: The FMLA Straddles Two Types of Employment Laws}

Federal statutes and regulations govern the relationship between employers and employees in a number of different ways. The National Labor Relations Act ("NLRA") sets standards and protections for unionization efforts in the workplace. ${ }^{21}$ Other federal employment laws provide certain minimum standards of employee treatment, prohibiting

17 Overview of Paid Sick Time, supra note 13; The Need For Paid Family Leave, A Better Balance, http://www.abetterbalance.org/web/ourissues/familyleave [https://perma.cc/N93Y] (last visited June 26, 2016). The federal Department of Labor's "LeadOnLeave" initiative includes an effort to encourage states and cities to enact paid leave laws. We're Ready to Lead on Leave, supra note 5. The initiative also proposes \$2 billion in new funds to support states' efforts to develop paid family and medical leave and \$1 million for state and municipality feasibility studies into paid leave programs. Id.

18 In 2015, Senator Kirsten Gillibrand and Representative Rosa DeLauro introduced the Family Medical Insurance Leave Act (FAMILY Act) which would provide up to twelve weeks of paid leave to care for a new child or seriously ill family member. Family and Medical Insurance Leave Act (the "FAMILY Act"), S. 1810, 113th Cong. (2013). This paid leave bill would create an insurance program funded by contributions from both workers and employers and administered through the Social Security Administration. Id. All workers who would be eligible for Social Security disability would be covered. Id.

19 Overview of Paid Sick Time, supra note 13, at 4-9.

20 Rafael Gely \& Timothy D. Chandler, Maternity Leave Under the FMLA: An Analysis of the Litigation Experience, 15 WASH. U. J.L. \& POL'y 143, 145 (2004) (“[T] o a large measure, the ultimate effect of a statute depends on litigation outcomes.").

21 National Labor Relations Act (NLRA), 29 U.S.C. § 151 (1935). 
unsafe work environments in the Occupational Health and Safety Act ("OSHA") ${ }^{22}$ and setting rules on child labor, minimum wage, and overtime in the Fair Labor Standards Act ("FLSA"). ${ }^{23}$ However, these benefit laws do differentiate among workers in some respect. For example, the FLSA requires overtime only for exempt employees with different impacts on different classes of workers ${ }^{24}$ and many of the NRLA protections only apply to employees who belong to a union..$^{25}$ These employment laws may nonetheless be distinguished from a second grouping of federal employment laws that base protections on an employee's membership in certain identity-based or inherent, "protected classes." Title VII of the Civil Rights Act of 1964 prohibits discrimination in employment on the basis of race, sex, color, national origin and religion. ${ }^{26}$ The Age Discrimination in Employment Act prohibits discrimination on the basis of age, and the Americans with Disabilities Act prohibits discrimination on the basis of disability. ${ }^{27}$

The FMLA and analogous leave laws are a hybrid of these benefit based and protectedclass based employment laws. ${ }^{28}$ On the one hand, leave laws resemble the first category and appear as neutral benefit laws. Although leave laws distinguish among employees, they do so not based on inherent characteristics such as race or gender, but rather status as caregiver or suffering from temporary physical illness. ${ }^{29}$ Anti-discrimination laws grant workers a right to sue their employers for discriminatory employment actions such as failure to hire, failure to promote, or termination. ${ }^{30}$ The FMLA and related leave laws, however, require the provision of direct benefits within the workplace. ${ }^{31}$ In this respect, leave laws mirror

22 Occupation Safety and Health Act (OSHA), 29 U.S.C. § 651 (1970).

23 Fair Labor Standards Act of 1938 (FLSA), 29 U.S.C. § 201 (2007).

2429 U.S.C. $\$ 207$.

2529 U.S.C. $\S 158$.

26 Civil Rights Act of 1964, 29 U.S.C. § 2000e-2(a)(1).

27 Age Discrimination in Employment Act of 1967, 29 U.S.C. § 623(a) (1991). Americans with Disabilities Act of 1990 (ADA), 42 U.S.C. $§ 12112$ (a) (2008).

28 Silbaugh, supra note 16, at 215 (The FMLA "unlike Titles VII and IX has as its purposes both an equality component and a family welfare component.").

29 See, e.g., Eyer, supra note 3, at 1280-81. See also Porter, supra note 12, at 333-34 (proponents of the FMLA designed it to be gender neutral to avoid "special treatment stigma" against women).

30 See, e.g., Title VII, 29 U.S.C. § 2000e-2.

3129 U.S.C. § 2612. 
statutes like OSHA or the FLSA which also mandate the standards within the workplace. ${ }^{32}$ An employee should not need to sue in order to receive the benefits of the law; rather, employers must generally comply. Lawsuits are in the outlier circumstances of failure to provide required benefits.

On the other hand, a deeper analysis reveals that leave laws do not fit quite so thoroughly into the same category as the FLSA or OSHA. First, by providing leave for an employee illness, leave laws overlap with the ADA and other such protected classbased laws that address individuals with disabilities. Moreover, although gender neutral in statutory language, the origin and use of leave laws closely tie these laws to gender. Activists and scholars long recognized that women's advancement in the paid economy required some means of addressing their greater role in childbirth, childcare, and other caretaking. ${ }^{33}$ The movement to create workplace leave was and continues to be driven in large part by a desire to improve women's position in the workplace. ${ }^{34}$ For example, two of the stated purposes of the FMLA are "minimizing employment discrimination based on sex" and "promoting the goal of equal employment opportunity for men and women." 35 In addition to this gendered origin, leave laws are mostly gendered in application. Thus, although men have an equal right to leave under the FMLA and related laws, women use

32 Albiston, supra note 1, at 134-35. ("The legal theory behind the FMLA is very different from the antidiscrimination provisions of the ADA and Title VII. The FMLA is based on the same principle as child labor laws, the minimum wage, Social Security, the safety and health laws, the pension and welfare benefit laws and other labor laws that establish minimum standards for employment.").

33 Rachel Arnow-Richman, Public Law and Private Process: Toward an Incentivized Organizational Justice Model of Equal Employment Quality for Caregivers, 2007 UtAH L. Rev. 25, $26-27$ (2007) ("With respect to gender, women have made significant progress in accessing market work but continue to lag behind men in such areas as job advancement, pay, and consistent workforce participation . . . The standard way work is organized - in forty-plus-hour weeks with no time off for childrearing or elder care — excludes many caregivers (mostly women, but also some men) from positions for which they are otherwise qualified.").

34 Kathryn A. Devinney \& Asafu Suzuki, Family and Medical Leave Act, 14 Geo. J. Gender \& L. 449, 453 (2013) ("Congress enacted the FMLA partly in recognition of [the] need for greater gender balance between work and family."); Porter, supra note 12, at 332 ("Much of the impetus [for the FMLA] appears to have been the desire to allow women to get pregnant and have babies while working without losing their jobs."). See also Rona Kaufman Kitchen, Missing the Mark: How FMLA's Bonding Leave Fails Mothers, 31 HoFstra LAB. \& EMP. L.J. 303, 306 (2014) ("Job-protected family leave was adopted primarily to ease work-family conflict experienced by women"); S. Elizabeth Malloy, The Interaction of the ADA, the FMLA, and Workers' Compensation: Why Can't We Be Friends?, 41 Branders L.J. 821, 827 (2002-2003) ("The FMLA reflects Congress's concern that the primary responsibility for family care mainly falls on women and that such family responsibilities greatly affect the working opportunities of women more than those of men."). 
these benefits to a much greater degree due to social norms expectations that place this care on their shoulders. ${ }^{36}$

\section{Context of Leave Laws: Litigated FMLA Claims}

The FMLA has over twenty years of case law, and these cases further demonstrate the hybrid nature of the statute. The FMLA creates two types of legal claims: interference claims $^{37}$ and discrimination claims. ${ }^{38}$ An interference claim is a denial of benefits claim that allows an employee to sue if the employer fails to provide the statutorily guaranteed leave. ${ }^{39}$ A discrimination claim is a retaliation claim that allows an employee to sue if the employer punishes the employee for exercising his or her FMLA rights. ${ }^{40}$ Interference claims differ from claims under federal anti-discrimination laws such as Title VII which require an employee to show that the employer acted with discriminatory intent. ${ }^{41}$ An FMLA plaintiff claiming interference is not required to prove the employer's intent; the mere denial of

36 Abt Assocs., Family and Medical Leave in 2012: Technical Report, 60, 64 (2012), http://www.dol. gov/asp/evaluation/fmla/fmla-2012-technical-report.pdf [https://perma.cc/EG8S-KBEQ]; Devinney \& Suzuki, supra note 34, at 464 ("Women are much more likely to use FMLA leave to care for others."); Porter, supra note 12, at 341-42 ("[B]y almost all accounts, the FMLA has not led to an appreciable increase in the number of men taking leave .... Those who take leave for family reasons are much more likely to be women .... According to some scholars, because women's role as the primary caregiver is socially constructed, it is not possible to change these gender norms through governmental intervention."); Gely \& Chandler, supra note 20, at 156 (The vast majority of FMLA plaintiffs are women - eighty-six percent. "Despite the gender neutrality of the FMLA, women are most likely to suffer adverse employment outcomes due to work-family conflict and, thus, have more frequent opportunities to benefit from the Act's protections.").

3729 U.S.C. § 2615(a)(1) ("It shall be unlawful for any employer to interfere with, restrain, or deny the exercise of or the attempt to exercise, any right provided under this subchapter.”); 29 U.S.C. § 2612 (describing the entitlement to leave).

3829 U.S.C. § 2615(a)(2) ("It shall be unlawful for any employer to discharge or in any other manner discriminate against any individual for opposing any practice made unlawful by this subchapter.") See also King v. Preferred Technical Group, 166 F.3d 887, 891 (7th Cir. 1999) (explaining the FMLA creates two types of claims, prescriptive, which is based on an employee's statutory rights, and proscriptive, which prohibits the employer from discriminating or retaliating against an employee for exercising these rights).

3929 U.S.C. $\$ 2615$ (a)(1); Sandra F. Sperino, Litigating the FMLA in the Shadow of Title VII, 8 Fla. InT'L U. L. Rev. 501, 510 (2013).

4029 U.S.C. § 2615(a)(2); Sperino, supra note 39, at 510.

41 See, e.g. Raytheon Co. v. Hernandez, 540 U.S. 44, 52 (2003) ("[L]iability in a disparate-treatment case depends on whether the protected trait actually motivated the employer's decision"). 
benefits for which the employee was in fact entitled is sufficient. ${ }^{42}$ An FMLA discrimination claim, however, does resemble anti-discrimination laws such as Title VII, in that it requires a plaintiff to prove the employer acted with a particular intent. ${ }^{43}$ Specifically, the plaintiff must show that the employer took a negative employment action against the employee and that the employee's exercise of FMLA rights was the motivation for the negative action. ${ }^{44}$ Thus, in FMLA discrimination claims, the employer's intent is at issue, but it is a different intent. Instead of having to show animus based on a protected characteristic such as gender or race, an FMLA discrimination plaintiff must prove the exercise of or attempt to exercise FMLA rights was the motivating reason. ${ }^{45}$

In FMLA discrimination claims, federal courts use the legal standards developed for proving intent in Title VII discrimination cases ${ }^{46}$ For example, courts apply the McDonnell Douglas three-part burden shifting paradigm developed in Title VII case law to FMLA claims. ${ }^{47}$ Moreover, defendants in FMLA discrimination claims use the same well-

42 Sperino, supra note 39, at 510 ("Once the plaintiff falls within the protected class of the FMLA and qualifies for its statutory entitlements, the employer's intent is not relevant to establishing liability under the interference provisions of the statute.") See also, e.g., King, 166 F.3d at 891.

43 "Confusion often arises as to whether an employee's FMLA claim is really about interference with his substantive rights, not discrimination or retaliation. The difference between the two claims is that the interference claim merely requires proof that the employer denied the employee his entitlements under the FMLA, while the retaliation claim requires proof of retaliatory intent." Stallings v. Hussmann Corp., 447 F.3d 1041, 1050-51 (8th Cir. 2006) (internal quotations omitted). See also Seeger v. Cincinnati Bell Tel. Co., 681 F.3d 274, 282 (6th Cir. 2012) ("If an employer interferes with the FMLA-created right to medical leave or to reinstatement following the leave, a violation has occurred," regardless of the intent of the employer ... [t] he central issue raised by the retaliation theory, on the other hand, is "whether the employer took the adverse action because of a prohibited reason or for a legitimate nondiscriminatory reason.") (internal quotations omitted); Sperino, supra note 39 , at 510 .

44 See, e.g., Potenza v. City of N.Y., 365 F.3d 165, 168 (2d Cir. 2004).

45 See, e.g., Ion v. Chevron, 731 F.3d 379, 390 (5th Cir. 2013).

46 Sperino, supra note 39, at 501. Henson v. U.S. Foodservice, Inc., 588 F. App'x 121, 125 (3d Cir. 2014) ("Courts generally look at FMLA retaliation claims 'through the lens of employment discrimination law' because such claims require proof of the employer's retaliatory intent.") (quoting Lichtenstein v. Univ. of Pittsburgh Med. Ctr., 691 F.3d 294, 302 (3d. Cir. 2012)); Ameen v. Amphenol Printed Circuits, Inc., 777 F.3d 63, 69 (1st Cir. 2015) (noting FMLA analysis borrows the McDonnell Douglas test from discrimination law to manage the "tricky issue" of intent).

47 Sperino, supra note 39, at 509. Sperino critiques the courts' use of this standard as harmful to the purposes of the FMLA. Id. at 509-10 ("[C]ourts have drawn the FMLA into the same framework morass that currently exists for Title VII discrimination claims. This phalanx of frameworks distracts courts away from the substantive core of the FMLA, and into endless arguments about the substantive and procedural oddities of the 
developed defenses from anti-discrimination statutes.$^{48}$ For example, one study found that the most common substantive defense to FMLA claims was that an employee's adverse employment outcome was not based on taking FMLA leave, but rather had a legitimate basis, a defense commonly found in discrimination suits. ${ }^{49}$ Overall, the jurisprudence of the most significant leave law, the FMLA, demonstrates its hybrid nature. In interference claims, the FMLA operates independently. In FMLA discrimination claims, courts use the legal standards from anti-discrimination statutes such as Title VII, but to find a different type of intent.

\section{Context of Leave Laws: Title VII Claims are Particularly Unsuccessful, FMLA Claims Fare Better}

It is particularly important to understand the degree of association between leave laws and anti-discrimination laws because anti-discrimination laws are particularly unsuccessful in court. "[E]mployment discrimination cases constitute one of the least successful categories at the district court level, in that plaintiffs win a very small percentage of their actions and fare worse than in almost any other category of civil case. ${ }^{\prime 50}$ On appeal, employment discrimination plaintiffs who have managed to succeed at trial are far more likely to be reversed than employment discrimination defendants or plaintiffs in other civil cases ${ }^{51}$ At the Supreme Court level, although some recent decisions show the complexity

frameworks."). Id. at 501.

48 Gely \& Chandler, supra note 20, at 160.

49 Id. at 160.

50 Clermont \& Schwab, From Bad to Worse, supra note 2, at 127 (Between 1979 and 2006, the plaintiff win rate in federal court for "jobs cases" (15\%) was dramatically lower than for "nonjobs cases" (51\%).). See also Michael Selmi, Why Are Employment Discrimination Cases So Hard to Win?, 61 LA. L. Rev. 555, 559-60 (2001) (describing plaintiffs' lack of success in discrimination cases, including that "[p]laintiffs in employment cases succeeded on only 18.7 percent of the cases tried before a judge, whereas the success rates for plaintiffs in judge-tried insurance cases was 43.6 percent and 41.8 percent for personal injury cases."); Joseph A. Seiner, The Trouble with Twombly: A Proposed Pleading Standard for Employment Discrimination Cases, 2009 U. ILL. L. Rev. 1011, 1015 (2009) (“[O]ver 80 percent of defendants' motions for summary judgment in employment discrimination cases are either granted or granted-in-part when decided by the district court"); Theodore Eisenberg \& Elizabeth Hill, Arbitration and Litigation of Employment Claims: An Empirical Comparison, 2009 U. ILL. L. Rev. 44, 48 (2009) (analysis of 1,430 employment discrimination cases heard in federal courts yielded an employee win rate of $36.4 \%$ ).

51 Clermont \& Schwab, From Bad to Worse, supra note 2, at 111-12. "The vulnerability on appeal of jobs plaintiffs' relatively few trial victories is more startling in light of the nature of these cases and the applicable standard of review. The bulk of employment discrimination cases turn on intent, and not on disparate 
of employment jurisprudence, ${ }^{52}$ many decisions have distinctly limited the impact of proemployee legislation. ${ }^{53}$ Indeed, on more than one occasion, the Supreme Court has so severely limited employee rights law that Congress amended the statutes to overturn the Court. ${ }^{54}$

The available data shows that FMLA claims, our best example of leave laws available, are indeed more successful than anti-discrimination claims. ${ }^{55}$

FMLA claimants win pretrial adjudications at roughly 4 times the rate of discrimination litigants, and prevail at trial in roughly $60 \%$ of cases, as compared to the roughly $30-35 \%$ trial victory rates of discrimination litigants. Indeed, the overall "win" rate for FMLA litigants is close to double the win rates for discrimination claimants (win rates that are strikingly similar (and low) across all of the various discrimination statutes, including Title VII, the ADA, § 1981 and the ADEA). ${ }^{56}$

Logic suggests that the hybrid nature of leave laws, specifically their status as at least partially benefit based laws, could explain the different outcomes. Further evidence, however, is necessary to understand what might be motivating the different judicial results for the FMLA, and by extension other leave laws. This understanding is important for the study of judicial decision-making in employment law and for activists seeking to construct effective workers' rights laws that address women's status and needs.

impact. The subtle question of the defendant's intent is likely to be the key issue in a non-frivolous employment discrimination case that reaches trial, putting the credibility of witnesses into play. When the plaintiff has convinced the fact finder of the defendant's wrongful intent, that finding should be largely immune from appellate reversal, just as defendants' trial victories are. Reversal of plaintiffs' trial victories in employment discrimination cases should be unusually uncommon. Yet we find the opposite." Id. at 112.

52 Even the conservative Supreme Court justices will, on occasion, issue pro-employee Title VII decisions. See, e.g., Young v. United Parcel Serv., Inc., 135 S. Ct. 1338 (2015) (conservative Justices Roberts and Alito supported the pro-employee, liberal outcome).

53 Kate Webber, It Is Political: Using the Models of Judicial Decision-Making to Explain the Ideological History of Title VII, 50 St. John's U. L. Rev. 1, 6-8 (2015) [hereinafter Webber, Title VII].

54 Id. at $8-10$.

55 Eyer, supra note 3, at 1352 (citing Clermont \& Schwab, How Plaintiffs Fare, supra note 3).

$56 \quad I d$. 


\section{Judicial Decision-Making on Leave Laws}

In an idealized scenario, expanded leave is implemented without judicial intervention because a leave law provides for an employee benefit as opposed to a civil right. As noted above, while an anti-discrimination law gives a wrongfully terminated employee the right to sue for damages, expanded leave laws mandate an employee benefit within the working relationship. Of course, in reality, judicial intervention is sometimes required to ensure employees are indeed receiving their benefits, to punish employers who fail to comply, and to deter others from doing so. ${ }^{57}$ The judicial role of enforcement may be particularly important for leave rights. Scholars of leave routinely find that even when leave benefits are available, employees - particularly male employees - are afraid to or unwilling to take them. ${ }^{58}$ These workers are constrained by a workplace culture that devalues leave and perceives those who do take it as deviating from workplace norms. ${ }^{59}$ The natural implication is that those who take leave may indeed face unlawful retaliation for which a civil suit is the necessary remedy. The data suggests that these plaintiffs have and may continue to have better results than anti-discrimination plaintiffs. Various theories of judicial decisionmaking, political, psychological and institutional, offer potential explanations for this difference.

\section{A. Political Science Theory: Leave Laws are More Successful Because They Are Less Controversial}

\section{Models of Judicial Decision-Making}

Political science scholars have developed theories on judicial decision-making based on empirical studies of a large body of decisions. ${ }^{60}$ These scholars developed methods of

57 Gely \& Chandler, supra note 20, at 145 ("[T] o a large measure, the ultimate effect of a statute depends on litigation outcomes.").

58 Bartel, et al., supra note 12, at 5; Jane WaldFogel, Bureau of Labor Statistics: Monthly Labor Report, Family and Medical Leave: Evidence from the 2000 Surveys, 18 (2001).

59 Cases demonstrate that this is occurring. See Joan C. Williams \& Allison Tait, "Mancession" or "Momcession"?: Good Providers, a Bad Economy, and Gender Discrimination, 86 ChI.-Kent L. Rev. 857, 865 (2011) ("Claims show that working men who openly demonstrate that they have caregiving responsibilities are viewed as less dependable, less ambitious and driven, and often engaged in gender-inappropriate work.").

60 Webber, Title VII, supra note 53, at 17. See, e.g., Richard L. Pacelle, JR., Brett W. Curry \& Bryan W. Marshall, Decision Making by the Modern Supreme Court 28-49 (2011). See also generally, Lee Epstein \& Jack Knight, The Choices Justices Make (1998); Jeffrey A. Segal \& Harold J. Spaeth, The Attitudinal Model Revisited (2002). 
measuring judicial ideology and used statistical analysis to test whether ideology influences decisions. ${ }^{61}$ The consensus among these studies is that ideology does play a meaningful role in decisions, particularly Supreme Court decisions. ${ }^{62}$ A number of studies also find ideology to play a role in federal circuit courts. ${ }^{63}$

Although there is consensus that ideology plays a role in judicial decision-making, political science scholars differ on whether ideological voting is constrained by other factors, such as the weight of precedent or the potential for congressional amendments of the law at issue. ${ }^{64}$ The attitudinal model of judicial decision-making holds that judges make decisions based on ideology and that only this factor has been empirically demonstrated with any certainty ${ }^{65}$ The strategic model asserts that although ideology influences judges, it is not the only influence; judges' decisions also reflect their concern that a case outcome might inspire a punitive response by the legislative or executive branches. For example, strategic modelists argue that the threat of legislative override or impeachment or reducing funding can temper the judicial desire for ideologically consistent case outcomes and cause a judge to vote contrary to ideology ${ }^{66}$ Other integrated models find that judges are

61 Webber, Title VII, supra note 53, at 17. See, e.g., SEgAL \& SPAETH, supra note 60, at 312-26; PACELLE, ET AL., supra note 60 , at $44,71$.

62 Sidney A. Shapiro \& Richard Murphy, Politicized Judicial Review in Administrative Law: Three Improbable Responses, 19 Geo. Mason L. Rev. 319, 321 (2012); Webber, Title VII, supra note 53, at 17. See also Mario Bergara et al., Modeling Supreme Court Strategic Decision Making: The Congressional Constraint, 28 LEGIS. STUD. Q. 247, 267 (2003) (strategic model study concluding that ideology influences the Court in addition to strategic concerns); PACELLE ET AL., supra note 60, at 53 (noting conclusion that Court decisions reflect "ideological predilections" among other factors); SEGAL \& SPAETH, supra note 60, at 312-26 (attitudinal model conclusion that ideology affects Supreme Court decisions).

63 See, e.g., Frank Cross, Decision Making in the U.S. Court of Appeals 38 (2007). However, “a large majority of the published appellate court cases are unanimous, maybe up to 85 percent." Shapiro \& Murphy, supra note 62, at 329, 330 (the effect of ideology on Circuit Court decisions is small).

64 See Webber, Title VII, supra note 53, at 18; Kate Webber, Correcting the Supreme Court-Will It Listen? Using the Models of Judicial Decision-Making to Predict the Future of the ADA Amendments Act, 23 S. CAL. INTERDISC. L.J. 305, 308-15 (2014) [hereinafter Webber, $A D A$ ].

65 Webber, Title VII, supra note 53, at 18. See also LeE EpSTEIn, William M. LANDES \& Richard A. Posner, The Behavior of Federal Judges 69 (2013); PaCelle, ET Al., supra note 60, at 34-36; Segal \& SPAETH, supra note 60 , at 86 .

66 Michael A. Bailey \& Forrest Maltzman, The Constrained Court: Law, Politics, and the Decisions Justices MaKe 97-101 (2011) (describing strategic model); PACELLE, ET AL., supra note 60, at 39-45 (same); Webber, Title VII, supra note 53, at 18. 
ideological in part, but also modify their decisions based on strategic concerns and a respect for legal principles such as precedent. ${ }^{67}$

The political science models of judicial decision-making offer a potentially useful heuristic for understanding current and future judicial interpretation of leave laws. Preliminarily, the ideology of leave laws is fairly logical-traditional conservative ideology resists workplace regulations such as leave laws while liberal ideology supports greater legal protection for workers. ${ }^{68}$ Consequently, under the attitudinal model, plaintiffs' success in enforcing leave laws would depend on whether the majority of the judges/ justices deciding the case are conservative or liberal. ${ }^{69}$ Under the strategic model, this ideological determinant plays a role but will be tempered by the ideology of Congress and the executive branch. ${ }^{70}$ Under the strategic model, at the time of a decision on leave laws, a judge will consider potential negative responses whether by an appellate court, legislative override, or executive punishment such as budget allocation. As a result, a judge's vote on a leave law may not be based solely on ideology, but rather would be mitigated in order to avoid these negative responses. Specifically, the judge's decision would reflect the position that is closest to the judge's desired ideological outcome as possible, but not so strident as

67 Integrated models find a role for the force of the law itself, but that it is just one of multiple factors. Webber, ADA, supra note 64, at 313-14. Significantly, political science theorists reject the naïve legal model that judges base decisions only on the law, and critique the legal academy for its embrace and teaching of this notion. Id. at 309-10. Some political science theorists do expand the analysis of judicial decision-making beyond the three models described here. See, e.g., EPSTEIN ET AL., supra note 65.

68 Webber, Title VII, supra note 53, at 4-5; see, e.g., Christopher Smith, Polarized Circuits: Party Affiliation of Appointing Presidents, Ideology, and Circuit Court Voting in Race and Gender Civil Rights Cases, 22 Hastings Women's L. J. 157, 160, 165 (2011) (a vote in favor of a race or gender civil rights claim is a vote in a liberal direction) (citing Cass R. Sunstein et al., Are Judges Political? An Empirical Analysis of THE Federal JudiciarY 19 (2006) (voting in favor of a discrimination plaintiff is liberal)). See also Harold J. Spaeth, The Supreme Court Database: Decision Direction, WASH. U. L., http://scdb.wustl.edu/documentation. php?var=decisionDirection [https://perma.cc/M5PV-L2WH] (last visited Feb. 26, 2014) (describing how this database of Supreme Court decisions coded "pro civil liberties or civil rights claimants . . anti-employer" outcomes as liberal and the reverse outcomes as conservative).

69 "[A]lmost twice as many sitting judges were appointed by Republican presidents than by Democratic presidents [which] disadvantages litigants that press liberal positions before the courts, such as environmental groups or civil rights groups." Shapiro \& Murphy, supra note 62, at 322.

70 Or the ideology of appellate judges. Much of the political science literature on decision-making is based upon studies of the Supreme Court. See, e.g., PACELle, ET AL., supra note 60. Some of the studies of the lower courts find that indeed appellate review is a mitigating force against the pursuit of ideological goals. See, e.g., EPSTEIN ET AL., supra note 65. 
to cause a reversal, override, or other similar reprisal. ${ }^{71}$ Finally, under the integrated model, both of these forces are at play, but judges interpreting leave laws may also be motivated by legal factors that may apply, such as precedent, and at least theoretically, the language of the statute itself. ${ }^{72}$

\section{Using the Models to Contrast Leave Laws and Anti-Discrimination Laws}

Although each model presents different views of the factors influencing decisionmaking, the one consistent message from these political theories is that ideology plays a role in judicial interpretation of leave laws. It is this aspect of political theory that offers a potential basis for understanding why leave laws have been and may continue to be more successful than anti-discrimination laws. This comparison is complicated by the FMLA's dual nature, with both benefit based and intent-based claims. ${ }^{73}$ It is the intent-based claims that have the most direct analogy to anti-discrimination laws; yet available data generally groups all FMLA claims together. ${ }^{74}$ Nonetheless, the comparison of anti-discrimination laws and the FMLA using political science studies does reveal useful information, particularly in light of the unique data on the judicial response to anti-discrimination laws.

A number of scholars, in a variety of contexts, have found that anti-discrimination laws trigger a particularly strong ideological response from the judiciary. ${ }^{75}$ For example, Jeb Barnes describes how the Supreme Court justices continued to follow their own conservative ideological preferences in Title VII cases even after Congress amended the

71 Bailey \& Maltzman, supra note 66, at 97-101; Webber, Title VII, supra note 53, at 18.

72 Webber, Title VII, supra note 53, at 18 n.119. See Bailey \& Maltzman, supra note 66; PaCelle, ET AL., supra note 60 . Studies finding legal factors to play a role are typically testing only the effect of precedential cases. The empirical evidence does not generally test for the influence of statutory language. Webber, $A D A$, supra note 64 , at $337-38$.

73 See Part I.B.1 supra.

74 See, e.g., Clermont \& Schwab, How Plaintiffs Fare, supra note 3, at 445.

75 Shapiro \& Murphy, supra note 62, at 337-38 (during the time period 1977-1987, "Democratic judges were 3.19 times more likely to make a liberal decision in race discrimination cases than were their Republican counterparts.") (citing C.K. Rowland \& Robert A. Carp, Politics and Judgments in Federal District CourTs 152-74 (1996)). See also Webber, Title VII, supra note 53, at 20-21, 28, 32. Relatedly, a number of scholars have found that ideological voting is most prevalent on salient issues, and that lack of salience can explain instances when judges appear to be voting contrary to ideological leanings. Webber, Title VII, supra note 53, at 23 (citing Unah \& Hancock, at*16-18; PACELLE, ET AL., supra note 60, at 202). 
law in 1991 specifically to override a series of more conservative Court decisions. ${ }^{76}$ Frank B. Cross and Blake Nelson similarly describe a conservative Supreme Court's ideological voting in Title VII cases, ignoring Congress' clear message that it intended a broader interpretation of the statute. ${ }^{77}$ A study by G. Mitu Gulati and Stephen Choi found that "the tendency to cite on the basis of ideology varies by subject matter," 78 and that for certain "hot button issues" including race, sex, and age discrimination, judges are even more likely to cite judges of the same political party and to not cite to opposite party judges. ${ }^{79}$ This empirical evidence of particularly strong judicial bias in employment discrimination cases is supported by anecdotal evidence as well. ${ }^{80}$

76 Webber, Title VII, supra note 53, at 32 (citing Jeb Barnes, Overruled?: Legislative Overrides, Pluralism, and Contemporary Court-Congress Relations 13-15 (2004) (noting for example that following the CRA, the Supreme Court still felt free to create its own employer-friendly standard for punitive damages, contrary to the language of the statute)). Jeb Barnes goes on to explain how judges appear to be particularly resistant to congressional restraint in cases involving "the statutory rights of discrete, insular minorities, such as African Americans or immigrants." BARNES, supra at 171.

77 Webber, Title VII, supra note 53, at 32 (citing Frank B. Cross \& Blake J. Nelson, Strategic Institutional Effects on Supreme Court Decisionmaking, 95 Nw. U. L. Rev. 1437, 1456-58 (2001)). See also Frank Cross, Decision Making in the U.S. Court of Appeals 112 (2007)

78 Stephen J. Choi \& G. Mitu Gulati, Bias in Judicial Citations: A Window into the Behavior of Judges?, 37 J. Legal Stud. 87, 91 (2008). See also Epstein ET AL., supra note 65, at 219 (noting that in district court decisions "employment and other discrimination cases tend to be decided more conservatively"); Cass R. Sunstein et al., Ideological Voting on Federal Courts of Appeals: A Preliminary Investigation, 90 VA. L. Rev. 301 (2004) (finding ideological effects in judicial voting patterns are stronger for certain categories of cases, including politically controversial areas).

79 Choi \& Gulati, supra note 78, at 91. ("These results support the view that bias is likely the product of the specific ideologies of the authoring judges."). Other distinct voting patterns emerge in anti-discrimination cases. For example, Sean Farhang \& Gregory Wawro found that women judges "were quite significantly more liberal than men in employment discrimination cases," despite lack of gender effect in other areas. Sean Farhang \& Gregory Wawro, Institutional Dynamics on the U.S. Court of Appeals: Minority Representation Under Panel Decision Making, 20 J.L. ECON. \& ORG. 299, 303 (2004).

80 "[T] he federal judiciary has become increasingly unfriendly towards employment discrimination cases going to trial. Those of us in the legal profession not living under a large rock would be hard pressed not to have noticed this." Mark W. Bennett, Essay: From the "No Spittin', No Cussin' and No Summary Judgment" Days of Employment Discrimination Litigation to the "Defendant's Summary Judgment Affirmed Without Comment" Days: One Judge's Four-Decade Perspective, 57 N.Y.L. Sch. L. Rev. 685, 697 (2013). "Judge Milton Shadur, of the Northern District of Illinois, wrote, 'When the close-of-discovery bell rings, the Rule 56 dog salivates. That almost instinctive response seems to be particularly marked in employment discrimination cases, with active encouragement of most courts of appeals ... " Id. at 692. "Judge Jack Weinstein, of the Eastern District of New York, also recognized ' $[t]$ he dangers of robust use of summary judgment to clear trial dockets," finding its use to be "particularly acute in current sex discrimination cases." Id. at 693. See also Selmi, supra note 50, 
As noted above, leave laws have a gendered aspect and history, as well as a connection to the protected status of disabled. These laws, however, also have a neutral application and, at least some aspects, such as leave for one's own medical condition, do not reflect the gendered issue of women's greater caretaking or protected class. As a result, leave laws such as the FMLA may trigger ideological responses - pro-employee support from liberal judges and anti-regulation opposition from conservative judges - but may not trigger the uniquely strong ideological responses of the anti-discrimination laws such as Title VII. Leave laws are pro-employee; however, they are not protected class-based. ${ }^{81}$ This crucial distinction possibly removes the FMLA from the "hot button," highly ideological realm of anti-discrimination statutes, and thus may not trigger the strongest ideological response from judges.

\section{Problems with the Ideology Analysis and Evidence}

The evidence that the FMLA is less controversial, however, is limited and indirect. While some political science studies analyze judicial decision-making on particular issues, the literature does not generally offer the degree of detail necessary to fully distinguish between different types of employment laws. ${ }^{82}$ Scholars have critiqued this lack of context. ${ }^{83}$ The stronger proof would be specific empirical data comparing the degree of ideological voting in FMLA cases in contrast to the degree of ideological voting in Title VII cases.

The ideology argument presents further challenges. FMLA claims do fare significantly better than Title VII claims. It is difficult, however, to demonstrate that this occurs because leave laws trigger a lower ideological response than anti-discrimination law. For example, the difference in case outcomes may simply be due to the FMLA's substantive differences from anti-discrimination laws. A fair portion of political science models accept that law constrains the ideological voting of judges, particularly at the lower court level.${ }^{84}$ According

at 556-57 (2001) (describing how judicial bias contributes to the unusual difficulty of proving employment discrimination claims).

81 Albiston, supra note 1, at 134-35. In the case of the FMLA, Congress specifically considered and intended for the law to avoid protected class-based rights. Id. at 135 .

82 If the premise is that leave laws are more successful because they are less ideological, FMLA cases should demonstrate more examples of judges voting contrary to their expected position based on ideology than cases involving Title VII.

83 Shapiro \& Murphy, supra note 62, at 329 (noting the lack of evidence as to how significant the influence of ideology is on case outcomes).

84 See, e.g., EPSTEIN ET AL., supra note 65, at 10-11, 253. 
to this version of political science thought, ideology is not the only factor in case outcomes, and it is therefore possible that different outcomes can be explained by different legal provisions rather than difference in ideological controversy. Significant legal differences do exist between the FMLA and Title VII. At least some types of FMLA violations are easier to prove than discrimination claims. For example, in claiming that an employer denied FMLA benefits, the employee will not have to show the employer had any ill intent ${ }^{85}$ Instead, the employee need only show entitlement and denial. ${ }^{86}$ In anti-discrimination statutes such as Title VII, however, the plaintiff must prove the employer's discriminatory intent, a much greater evidentiary challenge. ${ }^{87}$

At the same time, there is a category of FMLA cases that are intent based. Employees who took FMLA leave and subsequently experience negative treatment by the employer may have a claim for FMLA retaliation. ${ }^{88}$ This claim requires the employee to prove intent and for this analysis courts have borrowed the methods of anti-discrimination law. ${ }^{89}$ Specifically, courts have applied the Title VII McDonnell Douglas burden shifting analysis that allows an employee to prove intent by circumstantial evidence. ${ }^{90}$ Thus, to the extent the greater success of FMLA claims includes greater success on intent-based claims, this would suggests the difference in outcomes is not ease of proof, but rather some other factor such as a different degree of ideological controversy.

Some data suggests that in fact, FMLA intent claims, with the same evidentiary challenge of proving intent, still experience greater success than Title VII claims. Professors Gely and Chandler examined a body of FMLA cases, including a sub-category of cases where intent was clearly at issue, i.e. cases where the employee claimed she/he suffered an adverse employment event due to exercising FMLA rights and the employer claimed the event was due to legitimate workplace reasons. ${ }^{91}$ Gely and Chandler found that in those cases, employers won the vast majority of the time, with plaintiffs succeeding just thirty-five

\footnotetext{
85 Sperino, supra note 39, at 510.

$86 I d$.

$87 \quad I d$. at 509.

$88 I d$. at 510.

89 Id.

90 See, e.g., Rachel Arnow-Richman, Accommodation Subverted: The Future of Work/Family Initiatives in a "Me, Inc." World, 12 Tex. J. Women \& L. 345, 369-73 (2003).

91 Gely \& Chandler, supra note 20, at 165-66.
} 
percent of the time. ${ }^{92}$ This seemingly low number however, still compares favorably with the dismal success rate of discrimination cases overall. For example, in 2004 Clermont and Schwab measured the discrimination success rate at approximately seventeen percent. ${ }^{93}$ Thus, even when claims under both statutes raise the difficult issue of intent, the FMLA claims appear to fare better than Title VII claims. This raises at least some evidence that the difference in FMLA and Title VII outcomes is not due solely to substantive differences in the laws.

Even if evidence can refute law as the causal difference between FMLA and Title VII outcomes, affirmative proof of ideology as the causal factor remains elusive. Case law at the Supreme Court level does not add much clarity to the issue. In fact, the Supreme Court has only decided three FMLA cases. With a few exceptions, the overall voting patterns of all three cases match ideology with conservative justices voting in favor of the employer's position and liberal justices voting in favor of the employee's position. The significance of these votes is limited, however, given the dearth of cases. Moreover, all three cases involved other substantive issues which could have driven the votes: two of them involved issues of federalism and 11th Amendment immunity and one concerned the regulatory power of the Department of Labor. ${ }^{94}$

In Coleman v. Court of Appeals of Maryland, ${ }^{95}$ the Supreme Court issued a conservative ${ }^{96}$

$92 I d$.

93 Clermont \& Schwab, How Plaintiffs Fare, supra note 3, at 457. The 2004 data is the most contemporaneous to the Gely article. Gely \& Chandler supra note 20. More recent data places the Title VII win rate at approximately ten percent. Clermont \& Schwab, From Bad to Worse, supra note 2, at 117. This is only a rough comparison. The two success percentages are not directly comparable as the two studies look at different time periods and a different pool of cases. In addition the overall win rates from Clermont/Schwab incorporate Title VII, ADA, ADEA and FMLA claims. That said, when the Clermont/Schwab data separates out FMLA claims from other discrimination claims, in both 2004 and 2009, they find FMLA claims are still nearly twice as successful as Title VII claims. Clermont \& Schwab, How Plaintiffs Fare, supra note 3, at 445; Clermont \& Schwab, From Bad to Worse, supra note 2, at 117. Although the Clermont/Schwab data does not distinguish between FMLA intent and non-intent claims, it would not seem likely that such a large success differential would entirely arise from the non-intent claims.

94 Coleman v. Court of Appeals of Md., 132 S. Ct. 1327 (2012); Nev. Dep’t of Human Res. v. Hibbs, 538 U.S. 721, 725 (2003); Ragsdale v. Wolverine World Wide, Inc., 535 U.S. 81 (2002).

95 Coleman, 132 S. Ct. 1327.

96 See, e.g., Smith, supra note 68, at 165 (a vote in favor of a race or gender civil rights claim is a vote in a liberal direction) (citing SUNSTEIN ET AL., supra note 68 (voting in favor of a discrimination plaintiff is liberal)). See also Lee Epstein \& William M. Landes, Was There Ever Such a Thing as Judicial Self-Restraint? 100 
decision limiting the reach of the FMLA. In Coleman, the Court voted 5-4 along ideological lines. ${ }^{97}$ In Ragsale v. Wolverine World Wide, Inc., the Supreme Court issued a conservative decision on the FMLA..$^{98}$ The six-justice majority consisted of conservative and swing votes with three liberal justices dissenting. ${ }^{99}$ Although the presence of swing justices on both sides and Justice Stevens's conservative vote does not fit a standard ideological pattern, the overall predominance of conservatives in the majority and liberals in the minority does. Conservative Chief Justice Rehnquist authored the liberal opinion in Nevada Dep't. of

Calif. L. Rev. 557, 565 (2012) (using database to determine the ideological direction of the Court's decisions); Spaeth, supra note 68.

97 Conservative Justices Roberts, Alito, Thomas, and Scalia joined swing Justice Kennedy in finding that the "self-care" provision of the FMLA did not apply to state government employees. See Barbara A. Perry, The "Bush Twins"? Roberts, Alito, and the Conservative Agenda, 92 JudiCATURe 302 (2009) (describing Roberts and Alito as conservative); Erwin Chemerinsky, The Roberts Court and Criminal Procedure at Age Five, 43 Tex. Tech L. Rev. 13, 15 (2010) (identifying the conservative bloc of Roberts, Scalia, Thomas, and Alito); Richard G. Wilkins et al., Supreme Court Voting Behavior: 2006 Term, 36 Hastings Const. L.Q. 51, 57 (2008) (identifying conservative voting patterns of Scalia, Thomas, Roberts, and Alito). Coleman, 132 S. Ct. at 1339. See Injustice 5, Justice 4, N.Y. Times, May 31, 2007 (describing Kennedy as a swing vote); Wilkins et al., supra at 37 (same). Coleman, $132 \mathrm{~S}$. Ct. at 1332. The self-care provision allows employees to take time off under the FMLA for their serious medical condition. 29 U.S.C. § 2612(a)(1)(D). Liberal Justices Ginsberg, Breyer, Sotomayor, and Kagan dissented. See Charles D. Kelso \& R. Randall Kelso, The Constitutional Jurisprudence of Justice Kennedy on Speech, 49 SAN Diego L. Rev. 693, 694 (2012) (identifying the current liberal bloc as Justices Ginsburg, Breyer, Sotomayor, and Kagan); Chemerinsky, supra note 97, at 15 (identifying Justices Ginsburg and Breyer as part of the liberal bloc).

98 Ragsdale v. Wolverine World Wide, Inc., 535 U.S. 81 (2002) (overturning a Department of Labor regulation that had required employers to specifically designate leave as FMLA leave in order for an employee's time off to count against the twelve week FMLA entitlement).

99 Justices Rehnquist, Scalia, and Thomas, swing Justice Kennedy, and liberal Justice Stevens. Id. at 83. See James J. Brudney \& Corey Ditslear, Liberal Justices' Reliance on Legislative History: Principle, Strategy, and the Scalia Effect, 29 Berkeley J. EMP. \& LAB. L. 117, 120 (2008) (describing Stevens as a liberal justice); Michael C. Dorf, Does Federal Executive Branch Experience Explain Why Some Republican Supreme Court Justices "Evolve" and Others Don't?, 1 HaRv. L. \& Pol'y Rev. 457, 462 (2007) (describing conventional wisdom, confirmed by analysis of voting patterns, that Justice Burger was a conservative and Rehnquist even more so); Lori A. Ringhand, Judicial Activism: An Empirical Examination of Voting Behavior on the Rehnquist Natural Court, 24 Const. Comment. 43, 48 (2007) (describing Rehnquist's conservative voting patterns). Swing Justice O'Connor was joined in her dissent by liberal Justices Ginsburg, Souter, and Breyer. Ragsdale, 535 U.S. at 96. Brudney \& Corey, supra note 99, at 120 (describing Souter as a liberal justice). See Robert H. Smith, Uncoupling the "Centrist Bloc"- an Empirical Analysis of the Thesis of A Dominant, Moderate Bloc on the United States Supreme Court, 62 Tenn. L. Rev. 1, 3 (1994) (noting the common description of O'Connor as a centrist); Eric J. Segall, Justice O'Connor and the Rule of Law, 17 U. Fla. J.L. \& Pub. Pol'y 107, 134 (2006) ("For most of her time on the bench, Justice O'Connor served as the crucial swing vote."). 
Human Resources v. Hibbs, ${ }^{100}$ a surprising development much discussed among scholars of the Court. ${ }^{101}$ With the notable exception of the Chief Justice, the decision in this case falls along predicted ideological lines. ${ }^{102}$

Overall, the few Supreme Court cases available cannot by themselves establish that ideological voting is curbed in leave or family benefit law versus protected class cases.

It is possible that a larger pool of cases from lower federal courts could demonstrate whether ideological voting occurs in FMLA cases and to what degree. Data specifically analyzing this question, however, is unavailable. ${ }^{103}$ The most suggestive data is a difference in success rates depending upon the type of FMLA claim. The Gely/Chandler study found that FMLA claims arising from employees taking leave for pregnancy complications succeeded only $22.9 \%$ of the time while FMLA claims for leave related to the birth or adoption of a child succeeded in $41.9 \%$ of cases. ${ }^{104}$ Thus the claim most closely associated to the protected class of gender (women), is dramatically less successful than the more neutral benefit of time off to care for a new child in the household, which either men or women may take. It is the protected class status that political scientists and other scholars have found to trigger the most ideological response. ${ }^{105}$

\section{Conclusions on the Explanatory Utility of Ideology}

As detailed above, it would be useful to try to understand the difference in judicial response to leave laws in contrast to the highly unsuccessful anti-discrimination laws. One possible explanation is that leave laws such as the FMLA do not trigger as strong an

100538 U.S. 721, 725 (2003) (holding that Congress properly abrogated 11th Amendment immunity and that state government employees were entitled to the protections of the FMLA's family care provisions). Family care refers to the portion of the FMLA that allows qualified employees to take up to twelve weeks unpaid, jobprotected leave for the birth or adoption of a child or to care for a close family member suffering from a serious medical condition. 29 U.S.C. $\S 2612(a)(1)(C)$.

101538 U.S. 721 at 724.

102 Joining the Chief Justice were liberal Justices Souter, Ginsburg and Breyer, with liberal Justice Stevens joining in the outcome with a concurring opinion. Id. at 740. Conservative Justices Scalia and Thomas, as well as swing Justice Kennedy dissented.

103 Moreover, there is evidence that lower courts are not as ideological in their voting patterns in any event. See Epstein ET AL., supra note 65, at 10-11, 253.

104 Gely \& Chandler, supra note 20, at 165-66.

105 See supra note 75. 
ideological response as anti-discrimination laws. There is evidence that anti-discrimination statutes do trigger a uniquely strong ideological response, but incomplete (and at best indirect) evidence suggesting the FMLA is less ideological. As a result, it is useful to expand beyond political science theory to further understand judicial interpretation of leave laws, and in doing so address some of the other available theories of judicial decision-making.

\section{B. Psychology Theory: Leave Laws Avoid Unconscious Cultural Resistance}

An alternative theory of judicial decision-making is cultural cognition. Cultural cognition theory rejects the premise that judicial decision-making is consciously ideological and instead posits that decisions reflect the cultural and cognitive forces that subconsciously affect judges as they affect anyone. ${ }^{106}$ These cultural cognition models offer a different basis for understanding why plaintiffs suing under existing leave laws fare better than antidiscrimination plaintiffs. Significantly, although this is a different theoretical framework, the explanation remains the same: leave laws are and will be more successful than antidiscrimination laws because they are more "neutral" and avoid some of the controversies of laws based on protected class status.

\section{Cultural Cognition}

Cultural cognition is "the ubiquitous tendency of people to form perceptions, and to process factual information generally, in a manner congenial to their values and desires." ${ }^{107}$ This describes an unconscious psychological phenomenon where individuals selectively disregard information that contradicts their underlying values or outlook and overvalue information that is consistent. ${ }^{108}$ Under this perspective, judges are not "self-consciously

106 See, e.g., Paul M. Secunda, Cultural Cognition at Work, 38 Fla. St. U. L. Rev. 107, 108-09 (2010) [hereinafter Secunda, Cognition at Work] ("[C]ontrary to many commentators who have suggested that judging is generally an ideologically driven enterprise, Dan Kahan, Donald Braman, and other members of Yale Law School's Cultural Cognition Project have persuasively argued that such popular theories do not sufficiently explain the mechanism by which values influence judges."); Shapiro \& Murphy, supra note 62, at 337 (noting for example two scholars of the cognitive model who offered it as an alternative to the attitudinal model in their study of the federal district courts).

107 Paul M. Secunda, Cognitive Illiberalism and Institutional Debiasing Strategies, 49 SAN DiEGo L. Rev. 373, 374 (2012) [hereinafter Secunda, Cognitive Illiberalism]. See also, Shapiro \& Murphy, supra note 62, at 337; Secunda, Cognition at Work, supra note 106, at 112 ("Cultural cognition is a heuristic that comes to the legal academy from research conducted in the disciplines of anthropology and social psychology").

108 Secunda, Cognitive Illiberalism, supra note 107, at 380-81; Shapiro \& Murphy, supra note 62, at 337 ("[A]s a matter of individual psychology, 'it is much easier to believe that behavior one finds noble is also socially beneficial and behavior one finds base is dangerous rather than vice versa"') (quoting Dan M. Kahan, 
partisans" and they do "seek to arrive at the right decision without being ideologically committed to any prior legal or political view." 109 Instead, biased decision-making is the result of judges unconsciously bringing their own cultural perspective to bear. ${ }^{110}$

The biased decision-making resulting from culturally motivated cognition, is termed "cognitive illiberalism." 111 Thus, cognitive illiberalism makes judges vulnerable to betraying their commitment to neutrality by unconsciously applying their particular biases in interpreting a case. ${ }^{112}$ Cognitive illiberalism corrupts the legal decision-making process in a particularly insidious manner because individuals generally cannot identify when their unconscious cultural assumptions are slanting their interpretation of events. ${ }^{113}$

Professor Paul Secunda has identified cognitive illiberalism in various labor and employment contexts. ${ }^{114} \mathrm{He}$ asserts that the cultural cognition paradigm "provides a more robust explanation of how judicial values impact judicial decisions," than ideology based models of decision-making. ${ }^{115}$ As he explains, labor and employment decisions are the

"Ideology in" or "Cultural Cognition of" Judging: What Difference Does it Make?, 92 MARQ. L. Rev. 413, $413(2009))$.

109 Secunda, Cognitive Illiberalism, supra note 107, at 379; Shapiro \& Murphy, supra note 62, at 337.

110 Secunda, Cognitive Illiberalism, supra note 107, at 380; Shapiro \& Murphy, supra note 62, at 337 (describing the "cognition model" of judicial decision-making which describes judges as intending to let the law be their guide but ultimately voting in an ideological manner due to subconscious influence of cultural cognition). "Although some judges can rightly be accused of engaging in an outright ideologically motivated form of judicial bias, this Article maintains that the majority of judges are sincerely not engaged in this kind of ideologically based decisionmaking. Rather, a better and perhaps more helpful understanding is that . . beliefs feed on themselves within cultural groups, whose members stubbornly dismiss as unworthy insights originating outside the group." Secunda, Cognitive Illiberalism, supra note 107, at 381.

111 Secunda, Cognitive Illiberalism, supra note 107, at 380.

112 Id. at 383.

113 Id. at 383-84; Ann C. McGinley, Cognitive Illiberalism, Summary Judgment, and Title VII: An Examination of Ricci v. Destefano, 57 N.Y.L. Sch. L. Rev. 865, 874 (2013).

114 See, e.g., Secunda, Cognition at Work, supra note 106 (applying cultural cognition theory to a union labor case and to an equal protection public employment case); Paul M. Secunda, Cultural Cognition Insights into Judicial Decisionmaking in Employee Benefits Cases, 3 Aм. U. LAB. \& EmP. L.F. 1 (2013) (applying cultural cognition theory to employee benefits cases). See also McGinley, supra note 113, at 869-70 (finding cultural cognition explained the Supreme Court's decision to grant summary judgment to plaintiffs in Ricci v. DeStefano).

115 Secunda, Cognition at Work, supra note 106, at 109 (“'[H] owever one defines 'ideology,' the common 
type of case where cultural cognition is likely to occur because they frequently involve disagreements over legally consequential facts. ${ }^{116}$ "In the labor and employment context [cognitive illiberalism] transforms everyday legal debates over how to provide justice and fairness in the workplace into instances of political and legal status competition between management and labor interests." ${ }^{117}$ Naturally, this poses a threat to the ideal of fair decision-making in these cases. ${ }^{118}$

Other scholars have more specifically identified the ways that cultural biases and unconscious psychological presumptions affect decisions in employment discrimination cases. ${ }^{119}$ For example, Professor Katie Eyer demonstrates how preconceptions and other cognitive factors can cause decision-makers to be unconsciously less sympathetic to discrimination claims. ${ }^{120}$ As she explains, studies show that many Americans hold the belief that illegal or illicit conduct is rare, which decreases the willingness of decision-makers to attribute an employment action to discrimination. ${ }^{121}$ Similarly, the strongly held American belief in meritocracy ${ }^{122}$ makes decision-makers resistant to discrimination claims - to believe discrimination has occurred means meritocracy failed. ${ }^{123}$ Overall, "psychology scholars have documented that claims of discrimination trigger uniquely hostile responses from observers." ${ }^{24}$

ideological explanations for judges' behavior in workplace cases are inadequate.”).

116 Secunda, Cognitive Illiberalism, supra note 107, at 379-80.

117 Id. at 384.

118 Id. at 380.

119 See, e.g., McGinley, supra note 113.

120 Eyer, supra note 3, at 1346-48.

121 Id. at 1347.

122 "It is well-established that the overwhelming majority of Americans — of all groups and races—subscribe to some extent to meritocracy beliefs. Indeed, meritocracy beliefs are so widespread in the United States that they are frequently referred to as the dominant or national American ideology. Meritocracy beliefs can take a variety of forms, but typically center around a cluster of related beliefs that: (1) hard work gets you ahead in life; (2) advancement is possible for all individuals in American society; and (3) people usually get what they deserve based on their effort and skill." Id. at 1304

\section{Id. at 1304-07.}

124 Id. at 1348-49. "[C]laims of discrimination raise the specter of systemic deviations from meritocratic norms and thus trigger defensive responses." Id. at 1350. 
Leave laws such as the FMLA may be less likely to trigger the unconscious, negative psychological responses of cultural cognition, and this is an alternative explanation for why leave laws have and may continue to experience more successful litigation outcomes than discrimination laws. In fact, Professor Eyer presents a detailed case on how "extra discrimination remedies (EDRs)," including the FMLA, avoid the negative psychological reactions common to discrimination claims. ${ }^{125}$ As she explains, laws such as the FMLA do not signal group-based discrimination and therefore avoid the threat to the value of meritocracy ${ }^{126}$ which can unconsciously undermine a plaintiff's case. ${ }^{127}$ Moreover, to the extent leave laws such as the FMLA provide a more concrete standard for adjudication, these laws tap into a positive psychological phenomenon of decision-making that could lead to greater plaintiff success. ${ }^{128}$ Ultimately, Eyer concludes that to improve outcomes for victims of discrimination, plaintiffs must use the alternative approaches, such as the FMLA, that do not focus on protected class status. ${ }^{129}$

\section{Limitations of Psychological Theory and Possible Evidence of Family Friendly Viewpoint}

Cultural cognition offers a useful explanation for judicial behavior. In the context of the FMLA and other leave laws, however, the available studies only demonstrate the negative - the FMLA will not trigger as negative a response as anti-discrimination laws do. The case would be stronger with affirmative evidence that FMLA and similar laws actually inspire positive psychological responses in the judiciary. Some employment scholars have

125 Eyer, supra note 3, at 1347 ("[T]he prototypes that judges and jurors have in relation to many EDRs are likely to be much more plaintiff-favorable than commonly held discrimination prototypes. Insofar as the work of psychology scholars suggests that such prototypes influence outcomes, EDRs are thus likely to be better situated than discrimination claims to prevail.").

$126 I d$. at 1304.

127 Id. at $1349-51$.

128 Id. at 1350. "[P] sychology scholars have shown that well-defined and non-ambiguous constraints on decision-making . . . can be significantly more effective at constraining psychological biases ... than the type of weak constraints found in discrimination laws." Id. at 1350-51. The FMLA and leave laws are stronger constraints in the provisions that require distribution of benefits; while claims for retaliation for exercising benefit rights may not fall into this category due to the requirement of showing the employer's intent in the latter claims. See Part.I.C.2, supra.

129 Eyer, supra note 3, at 1280. "[T]aking seriously the findings of psychology scholars, it seems likely that EDRs will be uniquely situated to avoid many of the obstacles to litigant success that are posed by the restrictive and widely shared public views regarding discrimination." Id. at 1341 (discussing the use of "extradiscrimination remedies" or "EDR" to address inequality in the workplace). 
suggested, albeit without empirical proof, that such positive responses exist and identify a positive effect of "family values" in FMLA cases. For example, although not explicitly citing the cultural cognition heuristic, Professor Katherine Silbaugh identifies evolving cultural norms as affecting case outcomes in FMLA cases. Although cautioning that the trend was modest, she posits that FMLA cases have had greater success in lower federal courts as the issue of work-life balance has become "domesticated," that is, has moved beyond a feminist issue to a more "universal worker and family concern." ${ }^{30}$ To strengthen this connection, Silbaugh presents evidence of a cultural shift on issues of work-family balance. ${ }^{131}$

Professor Joan Williams has similarly noted that certain "family responsibilities discrimination" or "FRD" cases succeed because they appeal to a broader range of values. ${ }^{132}$ "FRD is employment discrimination against people based on their caregiving responsibilities - whether for children, elderly parents, or ill partners." ${ }^{133}$ FRD claims can be brought under various employment laws including the FMLA. ${ }^{134}$ " [One] reason for the success in FRD cases is that they are 'family values' cases that appeal to judges across the political spectrum, from liberal to conservative ...." ${ }^{135}$ These examples, while compelling, would be stronger proof of the FMLA and leave laws' ability to inspire positive judicial psychological response if paired with primary psychological studies documenting those responses.

Ultimately, although based on evidence of what the leave laws do "not" do, the implications of cultural cognition theory are useful and informative. The FMLA and similar

130 Silbaugh, supra note 16, at 198.

131 Including changes in employer practices, changes in cultural awareness and changes in political discourse, among others. Silbaugh, supra note 16, at 208-10. In another example, Professor Katherine Silbaugh identified the way sexual harassment cases have succeeded by tapping into conservative justices' values concerning proper workplace decorum. Id. at 214-15. "[S] exual harassment law came to be associated with ... a clumsy substitute for manners .... The notion that extreme sexual harassment is as much offensive as it is discriminatory made it easier for judges to condemn." $I d$. at 214 . As conservative judges associated sexual harassment prohibitions with their own values on decency, they issued more decisions in plaintiff's favor in these cases. Id. at 214-15. Silbaugh cautions that this phenomenon has negative implications. Id. at 215-16.

132 Joan C. Williams \& Stephanie Bornstein, Caregivers in the Courtroom: The Growing Trend of Family Responsibilities, 41 U.S. FLA. L. Rev. 171, 176 (2006).

133 Id. at 171.

134 Id. at 185.

135 Id. at 176. 
leave laws therefore have a basis for greater success than anti-discrimination laws because leave laws may not trigger the same negative cognitive response from decision-makers, and they may have a place within a broader range of values. Scholars have demonstrated the unconscious effect of cultural viewpoints and experiences on legal decisions. This cultural cognition plays a particularly strong role in employment law cases. Specifically, psychological studies demonstrate that protected class statutes such as Title VII provoke a distinct defensive responsive that makes it difficult for plaintiffs to succeed. In contrast, the FMLA, and by analogy other leave laws, do not implicate these unconscious negative reactions and appeal to a broader range of values. Thus, cultural cognition provides a useful theoretical basis for explaining the greater success of FMLA claims in comparison to antidiscrimination claims.

\section{Institutional Inequality: The Leave Laws Can Help Redefine the Ideal Worker}

Both the political and psychological paradigms for judicial decision-making offer reasonable explanations for why the FMLA is more successful for plaintiffs than the highly unsuccessful anti-discrimination laws. A third construct, institutional inequality, offers yet another potentially useful explanation for the different outcomes. Professor Catherine Albiston explains that institutional inequality is the way workplace expectations, such as availability from nine a.m. to five p.m., five days a week, can limit the advancement of women and the disabled. Under the theory of institutional inequality, judges view workers who cannot meet these norms as unqualified rather than viewing these norms as unnecessarily excluding particular groups. Professor Albiston asserts that the FMLA and similar laws can overcome this restrictive force in judicial decisions by statutorily redefining the "normal" workplace requirements. ${ }^{136}$

For example, the FMLA modifies the work norm of full-time work availability to allow for time off to care for a sick family member. Under Albiston's perspective, the FMLA is effective not because it is less ideological or more psychologically acceptable, but because it loosens the strict work requirements and expectations than can exclude women with caretaking responsibilities. Significantly, Albiston cites the same mechanism for the FMLA's superior results as both the political and psychological theories: it is a benefit statute creating primary workplace rules, as opposed to protected class statute prohibiting individual intent-based decisions. ${ }^{137}$

136 See generally, ALbiston, supra note 1.

137 Id. at $72-73,134$. 


\section{Institutional Inequality—The Ideal Worker is Defined and Normalized}

According to Albiston, institutional inequality is the way that norms and expectations for the institution of work exclude certain groups, particularly women and the disabled. ${ }^{138}$ Central to this phenomenon is the unchallenged premise that an ideal worker is available full time, year round, and provides uninterrupted labor. ${ }^{139}$ Under institutional norms, employers control both work schedules and how work is performed. ${ }^{140}$ Jobs or work that deviate from these norms are devalued; for example, part-time workers are excluded from benefit plans, or are paid less with less job security. ${ }^{141}$ This work culture limits the employment opportunities for those who cannot work regular schedules and often results in job loss for women and people with disabilities who need time off either to care for others or themselves. ${ }^{142}$

Work's institutionalized time norms are so pervasively accepted that "differential treatment of nonstandard workers seems unproblematic, natural, and fair." 143 Thus for example, a court will reject the claim of a female worker who claims discriminatory termination if she is fired for the "legitimate" reason of excessive absences. The court will not consider that the absences were for childcare and will not question whether the employer could have accommodated those absences without harm to the business. This inequality is institutionalized because the underlying rule that has unequal effect is not subject to challenge.

As Albiston notes, feminist scholars have previously identified the pernicious effects of these unquestioned workplace ideals. ${ }^{144}$ For example, generally, for a worker to both

\section{Id. at 70.}

139 Id. at 71. See also Williams \& Bornstein, supra note 132, at 173-74 ("Workplace norms continue to be defined as they were generations ago - designed around men's bodies and life patterns. From the employer's perspective, the ideal worker is someone who works full time, year round for years on end, without career interruptions, and with no domestic or childcare responsibilities.").

140 Albiston, supra note 1, at 32.

141 Id. at 32-33.

$142 I d$. at 72. "No matter how socially constructed they may be, conventional work practices have significant consequences for the economic and social status of women and people with disabilities." Id. at 35.

$143 I d$. at 35.

144 Albiston, supra note 1, at 34. As have disability scholars. Id. "Recent social models of disability note that institutionalized work schedules presume that workers can work full time without periodic interruption. 
have children and meet the time expectations of work, the worker must delegate childcare to another. ${ }^{145}$ Since women traditionally perform this caretaking role, work time norms assume and reinforce the traditional "solution" of gendered division of labor with men in the paid workforce and women providing unpaid labor at home. ${ }^{146}$ Consequently, women "disproportionately bear the losses that flow from deviating from standard work practices" in order to provide childcare, whether through the insecurity and lower pay of part-time status, inability to succeed or less success at full-time employment, or by working in the unpaid job of stay at home mother. ${ }^{147}$

\section{Institutional Inequality and Anti-Discrimination Laws}

As Albiston explains, courts solidify the harm of institutional inequality by adopting workplace time and presence norms in interpreting employment cases. ${ }^{148}$ Cases brought under anti-discrimination laws have been particularly susceptible to these confining judicial interpretations of work. ${ }^{149}$ "These cases indicate that as long as women seek equal access to work on its own terms, courts generally find in their favor. Challenges based on legal theories that implicitly or explicitly called into question time norms, however tend to produce doctrinal inconsistency and defeats for plaintiffs." ${ }^{150}$

Albiston provides examples of cases under the Pregnancy Discrimination Act ("PDA"), which is part of Title VII, ${ }^{151}$ where the employee misses work due to her pregnancy or

Devaluing nonstandard labor also tends to disadvantage workers who have disabilities that limit when and how much they can work. Social models of disability reject how individualistic, medical models locate barriers to work within the individual rather than in the socially constructed features of their environment." Id.

$145 I d$. Care for elderly or ill family members is similarly restricted. Id.

$146 I d$.

147 Albiston, supra note 1, at 34. The structure of work also has harmful effects on men. Id. at 78 ("[W]ork's historically contingent characteristics organize employment-related and non-employment-related social life in ways that construct the meaning of gender for both men and women.").

$148 I d$. at 70-71. ("Courts simply enforce the time standard of the full-time, punctual and always-ready worker despite legal reforms that attempt to change these practices when they exclude women, people with disabilities, and care-takers from the workplace.").

149 "[W]orkplace time standards seem to be impervious to restructuring by antidiscrimination law." Id. at 70.

$150 \quad I d$. at 80.

15142 U.S.C. $\S 2000$ e. 
complications of pregnancy. ${ }^{152}$ She finds that "[c] hallenges to workplace practices encounter more difficulty when pregnancy causes working women to violate institutionalized time norms." ${ }^{153}$ Courts in such cases have held that the PDA does not bar employers from firing these pregnant workers who must miss work unless the employer overlooks comparable absences of non-pregnant employees. ${ }^{154}$ When the employer follows typical work time norms, however, there often is no such example as all employees are simply expected to meet attendance requirements or risk termination. ${ }^{155}$ In this manner, courts accept as valid an employer's use of restrictive time and attendance norms, leaving "no doctrinal opening to demonstrate that alleged work requirements may not be related to the job, or that alternatives exists that do not penalize pregnant workers." ${ }^{156}$

As one specific example, Alibston cites to the case Dormeyer v. Comerica BankIllinois, in which the plaintiff was terminated for absences due to morning sickness. ${ }^{157} \mathrm{In}$ Dormeyer the Seventh Circuit reasoned that a plaintiff who could not meet the "legitimate requirements of the job," namely, the attendance requirements, could not bring a legal challenge under Title VII. Thus, the court did not allow the plaintiff to use the theory that the attendance policy had a discriminatory disparate impact on women and simply found her termination to be legitimate. As Albiston and other scholars explain, an alternative approach is to ask: is the forty-hour, nine to five workweek itself discriminatory to women or people with disabilities, particularly if it is not actually necessary for the production/ outcomes employers seek. ${ }^{158}$ Courts, however, have not embraced this definition of discrimination, resulting in institutional inequality. ${ }^{159}$

152 Albiston, supra note 1, at 84.

$153 I d$. at 83.

154 Id. at 84.

$155 I d$. at 85 ("Typically in these cases, other workers are treated just as badly as pregnant women ... ").

156 Id. at $85-86$.

157 Id. at 97.

158 Williams \& Bornstein, supra note 132, at 174 ("If employers design good jobs around men's bodies and life patterns - despite the fact that nearly half the workforce is women - that is sex discrimination.").

159 Albiston, supra note 1, at 80. ("A close analysis of Title VII decisions reveals that courts have left little doctrinal room for challenging facially neutral work practices that nevertheless construct the meaning of gender .... These cases indicate that as long as women seek equal access to work on its own terms, courts generally find in their favor. Challenges based on legal theories that implicitly or explicitly called into question time norms, however, tend to produce doctrinal inconsistency and defeats for plaintiffs. Despite evidence that institutionalized time standards disproportionately disadvantage women, courts typically interpret the PDA and 


\section{Institutional Inequality and the FMLA}

In contrast to anti-discrimination laws, the FMLA and similar leave laws have the potential to disrupt this pernicious aspect of institutional inequality. As Albiston explains, the solution to institutional inequality is to shift the focus "from who is protected by antidiscrimination statutes to what work should look like." 160 The FMLA and analogous leave laws do exactly what Albiston prescribes because they "focus on the structural features of work itself, rather than the identity of a class of persons protected by the law."161 As an example, the FMLA "restructures work time norms" of full-time work without significant absence by requiring job-protected, twelve weeks of leave for the arrival of a new child, care of a close relative or care for one's own serious health condition. ${ }^{162}$ Leave laws thereby force employers to acknowledge their employee's family responsibilities and, by providing leave on a gender neutral basis, challenge the implicit expectation that caring for family members is the responsibility of a worker's at-home spouse, rather than the worker him/herself. ${ }^{163}$ This ultimately undermines the ideal worker standard and its inherent exclusionary effects.

The ability of leave laws to challenge the definition of the ideal worker means plaintiffs may be able to avoid some of the more successful defenses under anti-discrimination law. ${ }^{164}$ As Albiston explains, an employer's usual attendance policies, evaluation criteria that considers absences, or policies against reduced work schedules cannot apply to employees

Title VII to reinforce work's culture of time.”).

160

Id. at 107.

161 Id. at 72-73, 134. ("Title VII and the ADA incorporate two different doctrinal models: an inequality model and an accommodation model, respectively. Title VII prohibits employers from treating workers differently on the basis of sex. The ADA not only prohibits discrimination, but also requires employers to accommodate workers' disabilities. Both statutes, however, create rights that are based on workers' identities. In contrast, the FMLA focuses directly on the characteristics of work. Rather than requiring equal treatment it creates a substantive right to up to 12 weeks of job-protected unpaid leave per year. In this way, it is more like legislation that creates job-protected leaves for jury duty or military service than anti-discrimination legislation. The FMLA's structural approach offers more doctrinal avenues for interrogating workplace time norms built around historical conceptions of gender and disability.").

162 Id. at 134.

$163 I d$. at $136-37$.

164 Id. at 138 ("Situations that under Title VII or the ADA often resulted in no relief for workers have different outcomes under the FMLA."). She cites two examples where pregnant employees were able to obtain FMLA leave because workplace conditions posed risks to their pregnancy. Id. at 138 . 
who qualify for FMLA protection. ${ }^{165}$ Thus, as Albiston explains, by directly mandating leave benefits, the FMLA prevents courts from relying upon employer schedule preferences to dismiss a plaintiff's claims. ${ }^{166}$ Similarly, mandated leave benefits avoid the confining equal treatment analysis under anti-discrimination laws. For example, Title VII permits employers to deny workers time off so long as the employer does so on an equal basis, which under standard norms leaves employees needing a different schedule without a legal claim. ${ }^{167}$ With the FMLA, however, the question is simply whether the employee received the benefit to which she or he was entitled, not what the standard practice is. ${ }^{168}$ In fact, "because leave is an entitlement rather than a discretionary benefit, an employer cannot defend against liability by simply asserting a legitimate business reason for denying leave," ${ }^{169}$ whereas a legitimate business reason for an employment action is the lynchpin of employer defenses to anti-discrimination claims. ${ }^{170}$ Thus, Albiston identifies the transformative potential of leave laws stemming from their departure from the protected class paradigm.

\section{Limitations}

Albiston acknowledges that the ability of the FMLA to challenge time norms is incomplete. She notes, for example, that the FMLA does not protect employees who change their schedule but do not reduce their work hours or take leave; which to a parent with specific hours of childcare availability can be just as crucial as time off of work. ${ }^{171}$ Nor does the FMLA provide for pregnancy accommodation other than leave, which fails to protect women who are capable and want to work during their pregnancy but simply need accommodation in order to do so. ${ }^{172}$

More significantly, Albiston also explains that institutional norms still influence

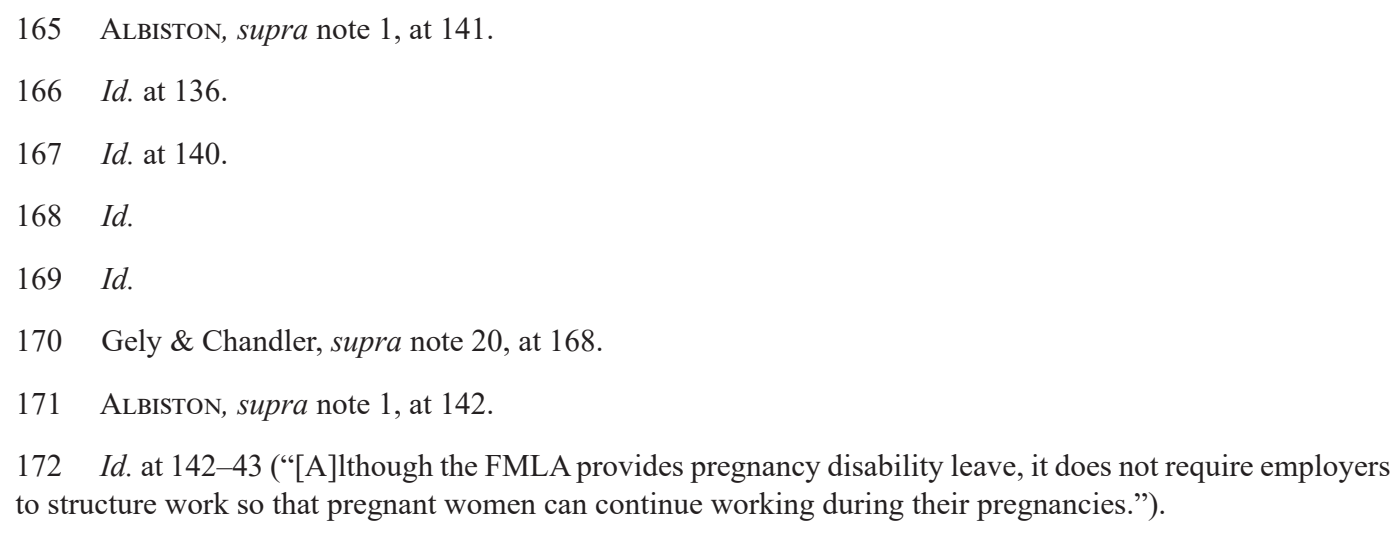


decision-making in FMLA cases at least to some degree. ${ }^{173}$ In particular, the FMLA allows employees to sue for denial of benefits, but also for claims that the employer "discriminated" against the employee for exercising her FMLA leave rights. ${ }^{174}$ In this latter category of cases, the Gely/Chandler study found that employers are successful in raising the defense that the adverse employment actions against an employee occurred for reasons unrelated to the FMLA leave such as violation of work policies or poor performance. ${ }^{175}$ This defense implicates the ethos of employer control of the workplace and employee responsibility to meet these norms, i.e., as soon as protected leave is over, institutional inequality is in full effect. ${ }^{176}$

Overall, however, Albiston presents a useful theoretical framework for understanding why and how the FMLA, and by extension other leave laws, are or will be more successful than anti-discrimination laws. Although unable to completely escape the force of workplace norms, Albiston explains how the FMLA and analogous leave laws might do so to a much greater degree than anti-discrimination laws. "Courts may be more willing to challenge institutionalized time norms in FMLA actions because the FMLA advances a legal theory of reform based on minimum workplace standards, rather than prohibitions against discrimination." ${ }^{177}$ Thus, legal reforms such as the FMLA that directly challenge

173 Id. at 143.

174 Sperino, supra note 39 , at 510.

175 Gely \& Chandler, supra note 20, at 165 ("Employers were most successful when defending themselves against alleged FMLA violations by claiming either that adverse employment actions experienced by employees occurred for reasons unrelated to their leave."). Employees succeeded in only thirty-five percent of cases in which the employer raised this defense.

176 Id. at 160-61. "[T] he most common substantive defense [in FMLA claims] was that the adverse employment outcomes experienced by employees were not based on taking FMLA leave (sixty-three percent of the cases) .... The business justification defense serves an important goal for the employer. In particular, employers want to be able to protect their ability to manage employees with as little interference from the courts as possible." In fact, Albiston analyzes a body of FMLA cases and finds that employers win a great majority of claims brought under the statute. AlBiston, supra note 1, at 215-18. This is also consistent with the Gely/Chandler results. Gely \& Chandler, supra note 20, at 163-64. Albiston further explains the "paradox of losing by winning" where cases that are strong for employees typically settle before reported decisions and employers as a collective interest, are repeat players with multiple opportunities to litigate the weaker cases to decision. See Albiston, supra note 1, at 193-99, 228. As a result, the body of case law on a rights statute such as the FMLA tends to be favorable to employers. $I d$.

177 AlBiston, supra note 1, at 240. 
norms, rather than prohibiting discrimination, are more likely to counteract institutional inequality. ${ }^{178}$

\section{Conclusions and Implications}

Legislative efforts to create workplace equality are inherently fraught with challenges. Political compromise shapes the laws, which are then placed in the hands of an entirely different branch of government for interpretation. It is at this latter stage of judicial decisionmaking where hard-won legal reform can be stifled by restrictive interpretation. If reform through the political system is to remain the path of change, advocates and legislators must craft bills with an awareness and understanding of potential judicial responses. The greater case success rates of the FMLA in contrast to anti-discrimination laws is an example of potentially relevant judicial patterns that can guide legislative strategies. The reasons behind these different outcomes therefore become significant. Various theories of judicial decision-making offer political, psychological, or institutional explanations. Although based on different premises, each of these theories suggests that judges have a less hostile reaction to the neutral benefit nature of leave laws in contrast to protected class-based anti-discrimination laws. Ongoing efforts to expand leave can perhaps then be pursued with some hope that they will avoid the markedly low rate of plaintiff success that antidiscrimination laws have experienced. Advocates can take this lesson in judicial outcomes to other contexts and design more effective legislative responses to inequality.

In fact, many of the recently proposed and enacted laws take this approach by mandating "family-friendly" benefits rather than prohibiting discrimination against particular classes of employees. For example, both federal and state legislators are seeking to pass laws providing for paid family leave to add to the FMLAs unpaid leave benefits. ${ }^{179}$ Not only do these laws use the more successful benefit structure of leave law, but they also particularly benefit low income workers who cannot afford time off without pay. ${ }^{180}$ Similarly, several states have passed laws providing for paid, short-term sick leave, which also mandate work benefits on a neutral basis rather than creating rights to sue based on status. ${ }^{181}$

In another key example, advocacy groups have proposed a federal Pregnant

179 See Part I, supra.

180 Porter, supra note 12, at 340.

181 See Part I, supra. These sick leave laws also particularly benefit low-income and hourly wage employees. 
Workers' Fairness Act ("PWFA"), which would require employers to provide reasonable accommodations to pregnant workers so long as they did not pose an undue hardship. ${ }^{182}$ The PWFA would prohibit employers from forcing pregnant employees to take leave when an accommodation would allow them to keep their job. ${ }^{183}$ Advocates for the PWFA suggest these accommodations could include things as simple as allowing an employee to take breaks to hydrate, providing a chair to use while working, to more impactful changes such as allowing pregnant employees to temporarily modify their schedule or lower their lifting requirements. ${ }^{184}$

The PWFA embraces the direct benefit model of imposing workplace modifications. This contrasts with the existing Pregnancy Discrimination Act, which is part of Title VII. The PDA prohibits discrimination based on pregnancy status and has a much more limited accommodation requirement. Albiston noted the weaknesses of the PDA in particular; specifically, under the PDA employers are not affirmatively required to provide accommodations to pregnant employees, no matter how easy it would be to do so. Instead, under the PDA employees must only provide the same level of accommodation provided to other employees with short-term limitations. In the context of workplace norms that do not allow extensive absence, the PDA fails to ensure pregnancy is accommodated.

The PWFA answers this specific weakness of the PDA by mandating benefits rather than requiring comparative status based equity. This difference should result in more positive judicial outcomes under the PWFA than the highly unsuccessful anti-discrimination laws. The statute will likely trigger less ideological responses, whether conscious viewpoint or unconscious cognitive illiberalism. ${ }^{185}$ Moreover, by reaching into the workplace to

182 S. 942, 113th Cong. (2013).

183 Id. A number of states have recently enacted similar laws. A Better Balance, Pregnancy Protections FOR WORKERS IN STATES AND LOCALITIES ACROSS THE U.S., http://www.abetterbalance.org/web/images/stories/ State_and_Local_PWFA_List.userfriendly.clean.01.13.16_pdf [https://perma.cc/9A3A-HK3N].

184 Nat'L Partnership, The Pregnant Worker's Fairness Act, http://www.nationalpartnership.org/ research-library/workplace-fairness/pregnancy-discrimination/fact-sheet-pwfa.pdf [https://perma.cc/8V9WX4A6]. In contrast to current law, employers would be directly required to provide these accommodations regardless of whether other workers with similar temporary illnesses are also provided the benefits. Id. The PWFA would further direct the Equal Employment Opportunity Commission to develop lists of model accommodations that should be provided in the absence of hardship. S. 942, 113th Cong. (2013).

185 Indeed, in a recent Supreme Court case, a number of conservative justices embraced the notion of pregnancy accommodation albeit in a more limited context. Young v. United Parcel Serv. Inc., 135 S. Ct. 1343 (2015) did not involve a leave law, but rather discussed the Pregnancy Discrimination Act (PDA) which is part of Title VII. The Supreme Court held that an employee may succeed under a claim of pregnancy discrimination 
restructure expectations for employees, the PWFA circumvents judicially endorsed notions of "legitimate" work requirements that can structurally exclude women workers. ${ }^{186}$ Overall, this statute and the many similar efforts by advocates at the national, state, and municipal levels are poised to reach beyond the limitations of the anti-discrimination statutes to have a more meaningful impact on the lives of workers.

where the employer fails to accommodate pregnant workers in the same manner as it accommodates other workers' inability to perform their tasks. $I d$. at 1361 . Contrary to ideological expectations, this pro-employee outcome was supported by Chief Justice Roberts and Justice Alito. Id. at 1356 (joined by liberal Justices Kagan, Sotomayor, Breyer, and Ginsburg).

186 AlBiston, supra note 1, at 97 (discussing the Doermeyer case). 